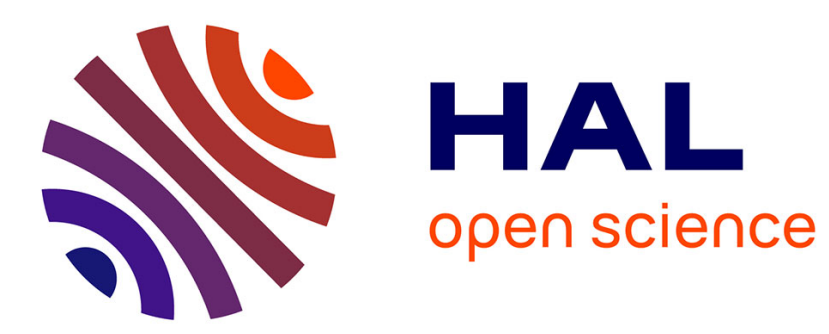

\title{
Representations of intellectual community in Plutarch, Pliny the Younger and Aulus Gellius Jason König
}

\section{To cite this version:}

Jason König. Representations of intellectual community in Plutarch, Pliny the Younger and Aulus Gellius. Archimède: archéologie et histoire ancienne, 2019, La République "gréco-romaine " des lettres: construction des réseaux savants et circulation des savoirs dans l'Empire romain, $\mathrm{HS} \mathrm{N}^{\circ} 1$, pp.54-67. halshs-02091584

\section{HAL Id: halshs-02091584 \\ https://shs.hal.science/halshs-02091584}

Submitted on 5 Apr 2019

HAL is a multi-disciplinary open access archive for the deposit and dissemination of scientific research documents, whether they are published or not. The documents may come from teaching and research institutions in France or abroad, or from public or private research centers.
L'archive ouverte pluridisciplinaire HAL, est destinée au dépôt et à la diffusion de documents scientifiques de niveau recherche, publiés ou non, émanant des établissements d'enseignement et de recherche français ou étrangers, des laboratoires publics ou privés. 


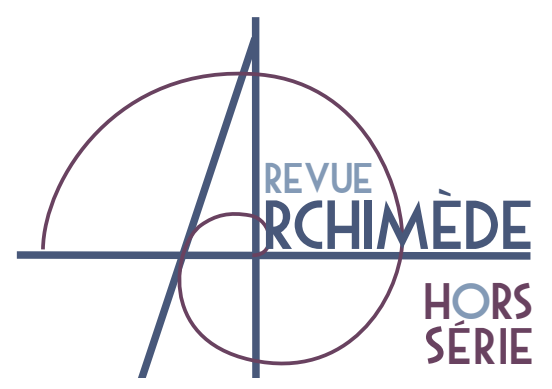

\title{
REPRESENTATIONS OF INTELLECTUAL COMMUNITY IN PLUTARCH, PLINY THE YOUNGER AND AULUS GELLIUS
}

\author{
Jason KÖNIG \\ Professor of Greek \\ University of St Andrews \\ School of Classics \\ jpk3@st-andrews.ac.uk
}

\section{ABSTRACT}

This chapter argues that the late first and second century CE was a period which saw important experiments with different possibilities for representing intellectual community. I look first at Plutarch's Sympotic Questions: his sympotic community is tied together by a shared style of conversation, which involves entering into dialogue with the authors of the past; it is also represented as a strongly Greek community, not least in the fact that so many of the conversations Plutarch records are set at festivals. Pliny's Letters are closely parallel to Plutarch's project: there is not enough evidence to demonstrate mutual influence between the two works conclusively, but Pliny does conjure an image of an elite community that shares the scale and variety of Plutarch's work, although with the difference that Pliny is much more interested in the portrayal of the book as a physical object, for example in his portrayal of recitation culture. For Gellius too Plutarch's Sympotic Questions is an important point of comparison, in fact Plutarch is one of the main inspirations for his work, but he too, even more so than Pliny, gives great prominence

\section{MOTS-CLÉS}

Plutarch,

Pliny the Younger,

Aulus Gellius,

intellectual community,

networks,

reading,

symposium,

recitation. to the act of reading; the elite community he presents also has far fewer named figures, and that difference reflects his interest in solitary engagement with the writings of the past as an essential complement to learned conversation.
Cet article montre que la période comprise entre la fin du $\mathrm{I}^{\mathrm{er}}$ siècle et le $\mathrm{II}^{\mathrm{e}}$ siècle ap. J.-C. a été témoin $\mathrm{d}^{\prime} \mathrm{im}-$ portantes expériences visant à explorer diverses façons de représenter des communautés intellectuelles. Les Propos de table de Plutarque sont envisagés en premier lieu : la communauté sympotique qu'il décrit est liée par un mode de conversation partagé, qui consiste à engager un dialogue avec les auteurs du passé. Elle est aussi représentée comme une communauté profondément grecque, notamment en ce que nombre des discussions rapportées par Plutarque se déroulent lors de fêtes helléniques. Les Lettres de Pline le Jeune offrent un parallèle avec le projet de Plutarque : si les témoignages ne permettent pas d'établir avec certitude une influence mutuelle entre les deux œuvres, Pline construit lui aussi l'image d'une communauté d'élites d'une ampleur et d'une diversité comparables à celle que décrit l'œuvre de Plutarque, bien que Pline vise bien davantage l'élaboration du livre comme objet physique, par exemple dans sa description d'une culture de la récitation. Pour Aulu-Gelle, enfin, les Propos de table de Plutarque constituent également un important élément de comparaison. Plutarque est à vrai dire l'une des principales inspirations de cette œuvre, mais l'auteur, davantage encore que Pline, accorde une place très importante à l'acte de la lecture. La communauté d'élites qu'il présente ne mentionne que quelques personnages, ce qui reflète son intérêt pour la confrontation solitaire avec les écrits du passé comme complément indispensable de la conversation érudite.
Keywords Plutarque, Pline le Jeune, Aulu-Gelle, communauté intellectuelle, réseaux, lecture, symposium, récitation. 
In any history of representations of intellectual community within western culture, the period from the late first to the early third century CE, with its explosion of prose writing in both Greek and Latin, would have to play a prominent role. It is a common stereotype that much of that literature looked back to the past, and that is true especially for sophistic rhetoric in Greek, but it is also striking that a large proportion of it deals with scenes from contemporary intellectual culture. In what follows I look at two particularly important landmarks from the beginning of this period: Plutarch's Sympotic Questions and Pliny's Letters. I also look at a third text from half a century or so later, Gellius' Attic Nights, which demonstrates the importance and enduring attraction of the ways of thinking about community that those two earlier writers pioneered.

That is of course not to say that the idea of intellectual community was an invention of the late first century. The Socratic dialogues of Plato and Xenophon are crucial models for Plutarch, as we shall see, as are Cicero's Letters for Pliny; and the elite institutions of symposium and recitation discussed below were of course very old ones. [1] Nevertheless, recent work on Latin literature in particular has shown that the reigns of Nerva and Trajan and Hadrian saw a new interest in literary interaction, involving an increase in the phenomenon of cross-fertilisation between contemporary texts, and also (particularly important for the purposes of this chapter) a heightened interest in portraying social as well as literary relations between contemporary authors. [2] My argument here, in line with that broader picture, is that each of these three authors experiments in original and influential ways with the shared resources of communal self-representation they inherit from earlier Greek and Latin literature. There has been quite a lot of work now on each of these three texts individually, but remarkably, they have not to my knowledge been

[1] The Roman institution of the recitation is said to have been founded by Asinius Pollio in 39 BCE: see WHITE 1993: 59-63 on that early history and its later development in Augustan poetic culture.

[2] See KöNIG \& WHITTON 2018 for the general point; that volume, which arises from a St Andrews project on "Literary interactions under Nerva, Trajan and Hadrian", focuses on Latin literary interactions; the current chapter examined together in any detail before. What I am to show here is that the distinctive features of Pliny and Gellius come more clearly into view when we set them against the markedly Greek, Plutarchan alternatives that were in circulation as they were writing. Plutarch's vision of philosophical community in turn becomes more sharply defined when we view it in the light of the Latin literary practices that he must have been familiar with. For all their similarities, as we shall see, they ultimately offer quite different ways of imagining elite, intellectual community.

\section{PLUTARCH}

Plutarch's Sympotic Questions is a collection of learned conversations (95 in total, in nine books) from a large number of symposia which stretch right across Plutarch's adult life. They cover a huge range of subjects, including literary, musical, mythological, scientific, philosophical, historical and sympotic topics. Each of the books opens with a preface which gives moralizing recommendations for sympotic conduct and sympotic conversation. Clearly one of Plutarch's primary goals in this work is to conjure up a powerful fantasy image of intellectual community. No doubt that image (like the parallel images conjured up by Pliny and Aulus Gellius) to some extent reflected and also influenced real-life practices of intellectual conversation and literary activity and elite conviviality. But I should stress from the start that my primary focus in what follows is the images themselves rather than their value as historical sources or the precise detail of their relationship with that wider social and cultural context. Plutarch is offering us an idealized portrait of a very distinctive style of social and literary interaction. To what extent is he original in that? Clearly sympotic literature had from the start presented images period too by giving attention to Plutarch. For a related discussion of images of community in this period, see ESHLEMAN 2012, who deals also with early Christian texts; her account focuses above all on strategies for community definition, and on the distinction between insiders and outsiders, whereas my main focus in what follows is on the social and literary practices that tied elite communities together. 
of learned, elite community. Plato's Symposium and Xenophon's Symposium in particular had projected memorable pictures of the philosophical community around Socrates and of the conversational inclinations of its members, all of whom were members of the Athenian elite. And Plutarch repeatedly refers to those works in the Sympotic Questions, as if to acknowledge what he owes to them. Nevertheless his approach is also in some respects very different, above all because he strings together such a large number of different conversations, in a way which allows him to integrate the traditions of the Socratic symposium with the miscellanistic and encyclopaedic styles of writing that were becoming more and more common from the first century CE onwards. [3] There may be precedents for that combination of symposium and miscellany from the Hellenistic world, but it is very hard to know for sure. We have several texts from Hellenistic Alexandria which represent the symposium as a space for learned conversation. [4] We also know the names of quite a few authors who wrote sympotic texts in that period, or works on food and drink. For example, in the preface to Book 1 of the Sympotic Questions (612d) Plutarch mentions not just Plato and Xenophon, but also Aristotle, Speusippus and Epicurus; also Prytanis and Hieronymus, who were Aristotelian philosophers from the third century BCE; and also another figure, Dio of the Academy, who seems to have been writing in the first century BCE. But we know very little about these works, and that makes it very difficult to judge the extent of Plutarch's originality. [5] Nevertheless it does seem likely to me that Plutarch was innovating significantly, given that Aulus Gellius (as we shall see) and Macrobius [6] seem to have viewed the Sympotic Questions as one of the most important models for their own writing, as if it was a foundational work for the genre of the sympotic miscellany.

What kind of community, then, does the Sympotic Questions present to us? The first thing to say is that it is a community united not just by shared knowledge of classical literature, but also by shared ways of talking. Plutarch and his fellow guests attach a very high value to speculation and ingenuity. [7] Often they take it in turns to offer different solutions to a problem posed by one of the guests. Often we have the impression that the process of searching for an answer is more important than the answer itself. And that style of conversation is one of the things that ties this sympotic community together. It also engages us as readers: we are invited to imagine how we would respond to these questions, almost as though we are participating in the conversation for ourselves.
For a typical example one might look at Sympotic Questions, 2, 2. Here we have a close-knit group of Plutarch's friends and family speaking together within a relatively playful atmosphere. They give several different explanations in turn for the fact that men become hungrier in the autumn:

At Eleusis after the mysteries, at the climax of the festival, we were dining at the house of Glaucias the rhetor. When the others had finished eating, Xenocles of Delphi, as he often did, began to tease my brother Lamprias about his "Boiotian gluttony". I defended him against Xenocles, who was a follower of the teachings of Epicurus, by saying, "Not all men, Sir, make the removal of what is painful the limit and perfection of pleasure. It is necessary for Lamprias, who honours the peripatos and the Lykeion ahead of the garden [i.e. Aristotelian ahead of Epicurean philosophy], to bear witness to Aristotle by his deeds; for Aristotle says that all men are hungriest in the autumn. And he has given the reason for that, but I do not remember it".

"All the better" said Glaucias, "for we ourselves shall try to search for it when we finish dining." $(2,2,635 a-b)[8]$

Glaukias' suggestion is followed by a series of speculative attempts at solution which culminate in Plutarch's own explanation: "And I, in order to avoid the impression of joining in the conversation without making a contribution, said that in summer we become thirstier and use more liquid because of the heat..." (635c) It is as though the process of speaking is more important than the result. When Plutarch and his friends contribute to the conversation they contribute also to maintenance of the sympotic community. Plutarch and other sympotic writers also celebrate another kind of community - that is a community which includes the authors of the past, who are quoted and referenced repeatedly within sympotic conversation. It is striking how often Plutarch describes the act of quotation via metaphors which suggest conversation or some other kind of personal contact,

[3] See KÖNIG \& WhITMARSH 2007; MORGAN 2011; KÖNIG \& WOOLF 2013.

[4] See KöNIG 2012: 12.

[5] See further TEODORSSON 2009.

[6] See KÖNIG 2012: 215-216.

[7] See KÖNIG 2012: 66-75; also FRAZIER \& SIRINELLI 1996: 195-207.

[8] All translations are my own, in some cases adapted from the Loeb Classical Library versions. 
as if classical authors like Plato and Euripides and others are actually being brought into dialogue with Plutarch and his fellow guests. [9] Plutarch talks about "repeating" what they have to say on a matter or "listening" to them or "conversing" with them. Sympotic Questions, 8, 2 is a typical example:

\begin{abstract}
After this, when silence had fallen, Diogenianus, making a new start, said, "Are you willing, since the conversation has turned to the gods, that we should invite in ( $\pi \alpha \rho \alpha \lambda \alpha \dot{\beta} \omega \mu \varepsilon v)$ Plato himself as

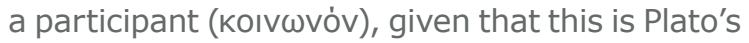
birthday, examining in what sense he intended the claim that 'God is always doing geometry'? if indeed that claim is to be attributed to Plato." $(8,2,718 b-c)$
\end{abstract}

The symposium was a powerful and popular vehicle for ancient miscellany not only because it allowed one to portray knowledge in action in real social situations, but also because it was well suited to this fantasy of entering into dialogue with the authors of the past. In Plutarch's case that imagery, along with the practice of quoting from memory, is so dominant that it comes to overshadow almost entirely any mention of books as physical objects to be read or consulted. [10]

Within the living community of symposiasts in the work one of the things that stands out its variety, which is nevertheless compatible with intimacy and harmony. [11] There is, for example, a wide range of different professions and different philosophical affiliations on show. [12] In Plutarch's world intellectual harmony arises out of friendly competition between these different perspectives and different kinds of expertise. Sympotic Questions, 2, 2 is a good example again: Plutarch and his fellow guests are dining at the house of Glaucias the rhetor; one of the speakers, Xenocles, is an Epicurean; another, Lamprias, is an Aristotelian; the conversation is driven forward by the friendly rivalry between their different perspectives. Plutarch's family is also prominent in the work: 2, 2 is again a good example, since Lamprias is Plutarch's brother; his father and grandfather also make regular

[9] See KöNIG 2012: 75-81; also BRÉCHET 2007.

[10] We see something similar in Athenaeus' Deipnosophists, 1, 4c: the dinner guests are described arriving at dinner laden with scrolls, but those books disappear from view throughout the rest of the work as it becomes clear that they are alive in the deipnosophists' memory. Cf. ZADOROJNYI 2013 for the point that other Greek authors from this period too are wary of giving libraries and books too much prominence. That said it is important to stress that Plutarch's hesitation about mentioning books as physical objects is not always so visible outside the context of the symposium: e.g. he regularly appearances. Moreover, this is a didactic community, full of young men learning from older mentors: in many of the quaestiones Plutarch represents himself as an older teacher figure surrounded by young men keen to learn, but elsewhere he appears as a young man early in his career. [13]

It is also a community with a very high degree of interlinking. Many of the guests turn up in several different chapters. This is a world where everybody knows everybody else (fig. 1). Figure 1 draws a line between each pair of guests who appear together at one or more symposia. The cluster on the left hand side is from the long series of quaestiones in Book 9: the book comprises fifteen conversations, rather than ten as in Books 1-8, all of which take place one after another on one occasion with an unusually large of speakers. But even if one discounts that cluster it is clear that many of Plutarch's characters are depicted repeatedly on different occasions, often with different fellow-symposiasts in each case. Plutarch's brother Lamprias is particularly important, as is his friend Philinus: both are linked to about fifteen others. The same goes for Plutarch's Roman patron Mestrius Florus. And there are many others with multiple connections on a slightly smaller scale.

One of the other distinctive features of Plutarch's imagined community, finally, is its geographical distribution. It includes a number of Roman guests, in line with Plutarch's interest in the way in which Romans can be improved by paying attention to Greek paideia. [14] This is a cosmopolitan community, then, an intellectual elite whose shared commitment to learning outweighs local differences. That said, it is important to stress that the work's conceptual geography is also quite tightly focused in some respects. Three settings recur particularly often: Athens, Delphi, and between them Plutarch's home town of Chaironeia in Boiotia. Rome is also mentioned as a setting three times. In addition, we see a range of different cities mentioned just once as settings, all of them either from northern Greece or from the Peloponnese. Also mentioned are a number of other places mentioned as

refers in prefaces to the act of sending his own books to his addressees, as we shall see in the section following for Sympotic Questions, 1, pr.; and for other examples (among many) see the prefaces to How a Young Man Should Study Poetry and On the E at Delphi.

[11] Cf. KöNIG 2012: 64-66; also KLOTZ 2007: 653 and KLOTZ 2011: 164-165.

[12] Cf. HARDIE 1992: 4754-4756.

[13] See KLOTZ 2007 and KLOTZ 2011.

[14] See SWAIN 1990: 129-131 on the Sympotic Questions. 


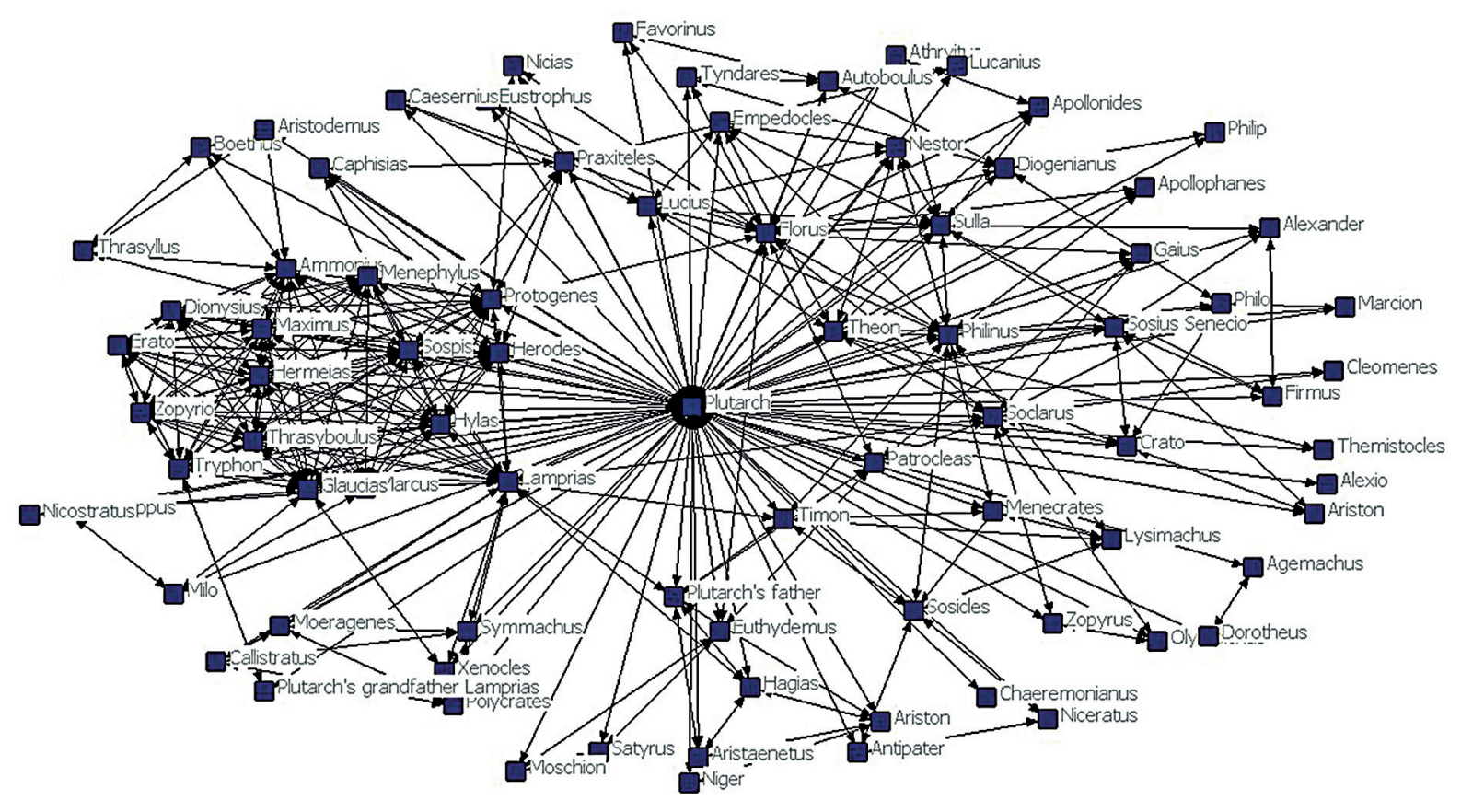

Figure 1 : Social network diagram for Plutarch's Sympotic Questions: lines indicate connections between individuals present at the same symposium.

the home cities of symposium guests, some of them in Asia Minor or North Africa. It is striking, however, that none of the settings for the dinner parties themselves is outside mainland Greece, apart from Rome: mainland Greece is clearly presented as the geographical and intellectual centre of the work, despite the cosmopolitan nature of Plutarch's guest lists.

Closely connected with that, as I have argued elsewhere, is the festive character of Plutarch's intellectual community in this work. [15] Approximately $25 \%$ of the conversations take place at festivals, including the very ancient Panhellenic festivals at Delphi and Isthmia. Often we see Plutarch and his friends at banquets in relatively small groups, some of them hosted by festival officials after the public business of the day is over. The implication is that their conversation parallels in some respects the official activities of the festival, but also that it is separate from them and perhaps elevated above them, in a way which is clearly intended to remind us of Socrates' refusal to attend the crowded victory banquet for Agathon in Plato's Symposium and his preference for the much smaller gathering of friends the day following. One particularly good example is Sympotic Questions, 8, 4, 723a:

When the Isthmian games were happening, during the second of Sospis' spells as agonothete, I avoided most of the dinners, when he entertained together many foreign visitors, and often all the citizens as well. Once, however, when he invited his closest and most scholarly friends to his home, I was present too.

Other authors in the imperial period too use agonistic festivals as metaphors for literary activity, and portray them as places for the enactment of literary community: Philostratus' Lives of the Sophists is an obvious example. [16] In Plutarch's case, as for Philostratus, that motif reinforces the sense that the community he is depicting is linked with the very ancient Panhellenic traditions of mainland Greece.

In summary: one of Plutarch's main aims in the Sympotic Questions is to construct an idealized imagery of an intellectual network. Each of his conversations has its own small-scale guest list, usually with only a few named guests in each conversation, but between them they represent a much wider community, even though we never see all of them together in one place. It is a very varied group, geographically and professionally, flexible enough to incorporate Roman guests as well as Greek. But despite that diversity it is also for the most part a very harmonious community. It is unified by certain repeated techniques of conversation, and heavily dependent on oral ways of recalling and interacting with the authors of the past. It is also unified by numerous links of

[15] See KöNIG 2012: 81-88.

[16] See KöNIG 2014. 
friendship and acquaintance. And it is a Panhellenic community, closely linked with the great festivals of mainland Greece with their traditional role as venues for intellectual display.

\section{PLINY}

How do the Latin writers of the same period compare in their representation of intellectual networks and literary community? As we shall see, both Pliny and Aulus Gellius have a great deal in common with Plutarch, but they also are also in some respects very different, above all because they are so obsessed with the practices of reading and writing, in contrast with Plutarch's focus on oral recall. Literary community in Rome, at least for these two authors, is always founded on engagement with the book as a physical object. [17]

I look first at some of the common ground between Pliny's Letters and Plutarch's Sympotic Questions before turning to the differences. To my knowledge the very striking similarities between these two projects have never been discussed in any detail. The first thing to say is just that Plutarch and Pliny could very easily have known each other, although we have no evidence that they did. Plutarch was born around $50 \mathrm{CE}$, so he was probably about ten or twelve years older than Pliny, who was born in 61. Plutarch spent most of his time at home in Boiotia after 96, but he clearly had spent a lot of time in Rome under Domitian. He and Pliny had lots of mutual friends. C. Minucius Fundanus was consul in $107 \mathrm{CE}$; he is Pliny's addressee in three letters; he is also a character in one of Plutarch's dialogues. Q. Sosius Senecio was consul twice; he is the addressee of two of Pliny's letters; he is also the addressee of Plutarch's Lives and his Sympotic Questions among other works; and he appears regularly in the Sympotic Questions contributing to the conversation as one of Plutarch's fellow-guests. He was also the son-in-law of Frontinus, who was one of Pliny's supporters. [18]
There are some even more intriguing points of connection when we turn to the works themselves. It is striking, for example, that their publication dates seem to be very similar: both works were clearly published in several instalments mainly in the first decade of the second century (although some of Plutarch's work may have been published after $110 \mathrm{CE}$, which is the latest possible date for Books 1-9 of the Letters). [19] Both of them look back to occasions well before the date of publication. They are also very similar in scale. The Sympotic Questions is just over 800 pages overall in the Loeb Classical Library series, although that figure would be nearer to 850 pages if we had the second half of Book 4, which is missing. It depicts 95 different conversations, in nine books. The first nine books of Pliny's Letters total 247 letters spread over 725 Loeb pages (or 371 letters over 870 pages if we count the correspondence between Pliny and Trajan in Book 10, which seems to have been published separately). We should probably not put too much weight on the precise similarity of length and book number; the important point is that these are works of roughly comparable scale. They also depict networks of roughly similar size. Both of them are in some sense works of biography, as recent scholarship has emphasized for both authors: they dramatise their authors' relationships with a wide range of others in the Greco-Roman elite. The Sympotic Questions has just under 90 named guests. Pliny names many more characters than Plutarch overall, many of them in passing, but the number of his addressees, just over 100, is similar to the number of named guests in Plutarch's work. Again it is not any precise similarity that matters; the important point is that both works are responses on a roughly comparable scale to the same challenge of representing an elite network.

The two works are also quite similar in the composition they imagine for their own communities. As we have seen there are lots of conversations in Plutarch with his grandfather or his sons or his various relatives by marriage. Many of Pliny's Letters are similarly
[17] See JOHNSON 2012 for fascinating discussion of reading communities in Roman culture, although without any attention to the alternative models of literary community represented by Plutarch and others.

[18] Plutarch was also well connected with other members of the Roman literary elite: see JONES 1971: 48-64 for an overview, especially 61 on the likelihood of a mutual acquaintance with Pliny; also JoHNSON 2012: 33, n. 9; and JONES 1971: 60 on Plutarch's acquaintance with Terentius Priscus, who is the dedicatee of Plutarch's On the Failure of Oracles, and was also a patron of Martial; that link between Plutarch and
Martial is also discussed at length by BALLAND 2010: 11-21.

[19] For Pliny's work, which must have been published before Pliny's departure for Bithynia in 110, see BODEL 2015; Plutarch's Sympotic Questions seems to date between 99 and 116: see JONES 1966: 72-73; FUHRMANN 1972: XXV-XXVI deals with the problem of dating rather differently, suggesting that the work was probably written mainly or entirely in the second decade of the second century; that would place it after the completion of Pliny's Letters. 
addressed to family members. Both of them are also culturally inclusive. They offer us an image of elite culture where movement between east and west is the norm, although they also both find ways of stressing the superiority of their own cultures when they are describing that exchange. Pliny's praise of the Greek philosopher Euphrates is a good example:

If ever liberal studies can be said to have flourished in this city of ours, now they flourish more then ever (si quando urbs nostra liberalibus studiis floruit, nunc maxime floret). There are many distinguished examples, but I need only name one, the philosopher Euphrates...His arguments are subtle, profound and elegant, so that he often seems to have something of the sublimity and breadth of Plato. His conversation is abundant and varied, with a special charm, which can captivate and so convince even reluctant listeners... But I don't know why I say so much about a person whose company I cannot enjoy?... For I am torn away by my duties, which are important but nonetheless tiresome. I sit on the bench, sign petitions, make up accounts, write countless unliterary letters (scribo plurimas sed illitteratissimas litteras). (Pliny, Letters 1, 10, 1-9)

The letter gives a broadly positive image of a mixed Greco-Roman intellectual culture. It is striking that Euphrates is described here in very similar terms to the way in which Plutarch is characterized in Lieve Van Hoof's recent work on the Moralia, as a philosopher who is unusually open to the perspective of political people who are not philosophical specialists, in other words as a philosopher who is well suited to mixing with the Roman elite. [20] That said, Stanley Hoffer has argued that Pliny is quite critical of Euphrates here, even though he appears to be praising him, and critical especially of Euphrates as a Greek. [21] Hoffer perhaps overstates that case, but certainly it is clear that Pliny emphasizes his own difference from Euphrates at the end of the letter, in explaining that he doesn't have time for Greek philosophy because he has to go off and do his legal work, like a good Roman. [22]

The final point of similarity I want to draw attention to is a more formal point: these two works also have similarities in the way they are organized. Both are miscellanistic. They cover a very varied range of subjects. They are not structured in a completely clear or consistent way. They share one very striking prefatory motif - that is the claim that they have ordered their works at random, or at least as the material came to mind. And yet both do have significant clusters of order and thematic interconnection, which makes that prefatory claim seem rather disingenuous on closer reflection. [23] In Pliny's opening lines we have the following:

You have often urged me to collect and to publish any letters I had composed with some care. I have now collected them, without preserving their chronological order (non servato temporis ordine) - since I was not writing a history - but as each of them came to hand (ut quaeque in manus venerat). (Pliny, Letters, 1, 1, 1)

That is very close to what we find in Plutarch's preface to Book 1, where Sosius Senecio has asked him to write:

You thought that I should collect whatever material was suitable from the learned conversations which have taken place often here and there

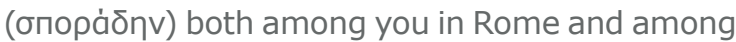
us in Greece, with table and cup before us. I have applied myself to that task and now send you three of the books, each containing ten questions... (Plutarch, Sympotic Questions, 1, pr., 612e)

Even more important as a parallel is the preface to Sympotic Questions Book 2, where he claims, rather disingenuously, that the work "has been written up

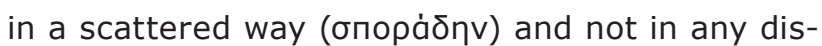
tinct order, but instead as each topic occurred to my memory" (2, pr., 629d).

Both Pliny and Plutarch, then, use idea of writing on request side by side with the motif of random organisation. Both of these are standard motifs in the prefaces of knowledge-ordering texts from the
[20] VAN HOOF 2010.

[21] HOFFER 1999: 118-140.

[22] Cf. UDEN 2015: 89-94 on the way in which Pliny's Letters attest to the influx of Greek intellectuals in Rome and the increasing cross-fertilisation between Greek and Roman culture, while also in some respects resisting those developments.

[23] Pliny's claim in particular has been shown to be dubious: see SHERWIN-WHITE 1966: 21-23 and 42-51,
MARChesi 2008: 12-52, Gibson \& Morello 2012: 234-264 and MARCHESI 2015, especially the essay in that volume by BODEL 2015; also KÖNIG 2012: 66-75 on order in the Sympotic Questions; and cf. VARDI 2004: 169-179 who draws a contrast between what she sees as the genuinely random structure of Gellius' miscellany, and other miscellanistic works where we find much clearer signs of thematic grouping (with brief mention, p. 169-170, of the Sympotic Questions, along with works by Athenaeus, Macrobius, Clement and Solinus). 
Roman Empire. [24] My argument here is that the second in particular functions effectively as a marker for the genre of the miscellany from the mid first century onwards. There are plenty of examples from the second century and after, as I have shown elsewhere [25] (for example in Aulus Gellius, [26] Clement of Alexandria, [27] Pollux, [28] Artemidorus, [29] Solinus [30] and Photius [31]), but it is surprisingly difficult to find instances of this motif before Plutarch and Pliny. There is one obvious classical precedent in the words of Socrates at the start of the Apology, where he promises that his audience will hear things "spoken at random, with the words that come to mind" (Eikñ

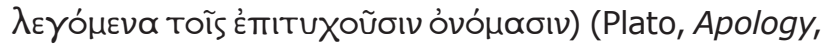
$17 \mathrm{~b}-\mathrm{c})$, in contrast with the more orderly speeches of the prosecution. There are some negative examples too, where that random way of speaking is characterised as something to be avoided. One example is Isocrates, 12, 24, who dissociates himself from "those who speak in a random, slovenly, and scattering manner whatever comes into their heads to say". But to my knowledge the only miscellanistic use before Trajan is from the miscellany of Pamphile, probably written under Nero, as reported by Photius. Photius tells us that she claims to have written deliberately "at random and as each thing occurred" (Eikñ kai ẃs

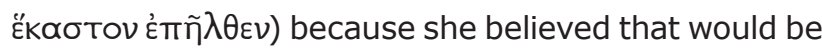
more agreeable to her readers. [32]

Plutarch and Pliny both use that common motif, and they are among the first writers to do so in the context of making claims about the structure of a whole work. How do we explain that? Obviously Pliny's main influence here may well have been the earlier letter tradition, especially Cicero, whose books of letters too often have a kind of superficial randomness, with underlying order just beneath the surface. [33] Most people think that Pliny is drawing on the varied structure of Latin poetry collections as a model for the miscellanistic organisation of his letter collection, which similarly combines the impression of spontaneity with careful organization and interconnection. Several scholars have talked about Ovid's Epistulae ex Ponto, 3, 9, 53 ("later collecting them anyhow I joined them"; postmodo conlectas utcumque sine ordine iunxi) as a model for Pliny's claims about randomness in that opening letter. [34] But it is surely perfectly possible that there was some cross-fertilisation between that poetic tradition and the structuring conventions of the Greek prose miscellany, and that Pliny might have been aware of the latter; or conversely that Plutarch may have been aware of the use of that motif and the techniques associated with it in Latin collections as well as in Greek miscellany writing.

In summary, it seems to me that it is at least conceivable that there was some influence in one or other direction between Plutarch and Pliny. Plutarch spent many years in Rome, and he and Pliny had mutual friends, as we have seen. It is hard to imagine that he knew absolutely nothing about Latin literary practice. [35] Most people think now that Plutarch knew more Latin than he claims. [36] And there are good
[24] See KöNIG 2009 on the claim that one has been asked to write, arguing (with reference to Galen) that we should take prose prefaces more seriously as vehicles for literary self-fashioning: they have their own generic conventions, which are often treated in very creative ways; cf. WHITE 1993: 64-78 on literary requests in Latin prose texts.

[25] For more detailed illustration of that point, with special reference to Pollux's Onomasticon, see KöNIG 2016.

[26] Gellius, Attic Nights, preface, 2-3; cf. HoLfordSTREVENS 2003: 34

[27] Clement, Stromateis, 6, 1, 2.

[28] Pollux, Onomasticon, 1, pr.

[29] Artemidorus, Oneirocritica, 3, pr.

[30] Solinus, Polyhistor, pr., 3-4.

[31] Photius, Bibliotheca, pr.

[32] Photius, Bibliotheca (cod. 175). There is no particular reason to doubt Photius' report, although it is striking that this phrasing echoes the language of his own preface (mentioned already above); quite possibly Photius is modelling his own miscellanistic language on Pamphile, but it is not impossible that he may be adjusting the wording of her preface to bring it more in line with his description of the Bibliotheca's structure.
[33] See BEARD 2002: 121 for further bibliography.

[34] See SYME 1985: 176; MARCHESI 2008: 20-22; WHITTON 2013: 11-13; BODEL 2015: 52, none of whom mention the overlaps with the Greek miscellany tradition; VARDI 2004: 173 is a rare exception.

[35] See below on Sympotic Questions, 7, 8, for one example of Plutarch's awareness of Roman literary customs.

[36] The key passage is Life of Demosthenes, 2: "having had no leisure, while I was in Rome and other parts of Italy, to exercise myself in the Roman language, on account of public business and of those who came to be instructed by me in philosophy, it was very late, and in the decline of my age, before I applied myself to the reading of Latin authors". For wide-ranging discussion, see RUSSELL 1973: 54, reacting partly against what he view as the excessive pessimism about Plutarch's knowledge of Latin in JONES 1971: 81-87. Certainly it is the case elsewhere in imperial literature that claims about ignorance of a particular language often refer to a lack of high-level literary competence, rather than a lack of dayto-day fluency. The most famous example is perhaps the image of Dio Chrysostom standing in Trajan's chariot from Philostratus' Lives of the Sophists: Philostratus tells us that Trajan claims not to understand what Dio is saying to him, but it seems more or less certain that Trajan would have been fluent in Greek: see STADTER 2002: 7-8. 
reasons to be suspicious of the common assumption that Greek writers of this period are never influenced by Latin ones. [37] Pliny in turn had plenty of contact with Greek literary and philosophical figures, as we have seen already from his mention of Euphrates, even if he makes no mention of Plutarch.

Ultimately, however, it seems to me that that question of influence is not the one that matters most. The more important point here, I suggest, is that both of these works are doing something very similar. They are both manifestations of a renewed interest in images of elite community which emerges in this period. Both of them share the goal of conjuring up a rich and complex fantasy image of intellectual and social interaction. In that sense they represent similar reactions to a set of shared challenges and shared opportunities in elite culture under Trajan.

There are also, however, some very striking differences between them. Here I want to focus on their very different attitudes to the role of the book as physical object within the communities they describe. Pliny's Letters are famously packed with mentions of literary activity, accounts of reading and writing. [38] By contrast, as we have seen, Plutarch's world is not a world where the physical acts of writing and picking up books and reading get much mention at all. There are occasional brief exceptions in Plutarch in his prefaces, where he talks about his own composition of the Quaestiones convivales itself in ways which are quite close to Pliny. The preface passages already quoted above are obvious examples: both Plutarch and Pliny refer to a request to publish and tell their addressee about the written material they are sending. Even in Plutarch's prefaces, however, his different approach to orality and written culture have an impact on his choice of imagery. Pliny tells us that he has arranged the letters "as each of them came into my hands" (Letters, 1, 1, 1). Plutarch, by contrast, explains in his preface to Book 2 that he has collected the conversations "as each of them came

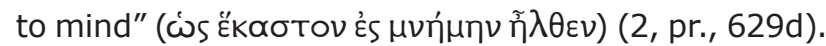

For Plutarch, as we have seen, the festival and the festival banquet are key venues for elite community. For Pliny, by contrast, the key institution of literary practice is the recitation where Pliny and his elite peers read out their latest compositions. [39] William Johnson counts 24 mentions of recitation in his work. [40] 1, 13 is a good example. The letter is addressed to Sosius Senecio, who is also of course the addressee of Plutarch's Sympotic Questions as well as the Lives. Pliny opens as follows: "This year has produced a good crop (magnum proventum) of poets; in the whole month of April there was scarcely a day when someone was not giving a recitation" $(1,13,1)$. The harvest imagery there suggests abundance, and perhaps implies an organic connection between the soil of Rome and the recitations it has nurtured. Pliny then goes on, however, to complain that many people go to recitations less often than they should, and that the audiences who do attend fail to pay attention properly. In that sense the intellectual community he is envisaging there is much less harmonious than the one we find in Plutarch. Nevertheless the point remains that both of them are doing their best to conjure up an image of what elite intellectual exchange should ideally involve - and even in the very positive terrain of the Sympotic Questions there are plenty of examples of undesirable sympotic behaviour. [41] We might also compare their views on the reading of books over dinner. Letters, 3, 1 is one example of many. [42] Here Pliny is praising the day-to-day regime of Spurinna:

Having bathed he lies down and for a little while postpones his food, and listens while something light and soothing is read to him...The dinner is often punctuated by comedy, so that pleasure has a seasoning of study. $(3,1,8-9)$

Plutarch does mention joint readings (ouvava$\gamma \nu \omega \dot{\sigma \varepsilon \sigma} v$ ) of Plato in company (but not explicitly in a symposium context) at Sympotic Questions, 7, 2,
[37] For a good example more or less contemporary with Plutarch and Pliny see the preface to Aelianus Tacticus' Tactical Theory, where he describes engagement with Frontinus.

[38] See Johnson 2012: 32-62; cf. Woolf 2003 on the widespread image of Rome as a centre of literary interaction.

[39] See JoHNSON 2012: 42-56; also GURD 2012: 105-126 on the way in which Pliny uses both recitation and the circulation of draft work among friends as ways of constructing community; and for the Roman connotations of recitation in Pliny's text, see UDEN 2015: 94-98, who views his championing of recitation as an attempt to resist the encroachment of Greek rhetorical display into Rome.

[40] JOHNSON 2012: 43.

[41] E. $g$., see the angry foreign guest at the opening of Sympotic Questions, 1, 2.

[42] Cf. 9, 36, 4: "If I am dining just with my wife or with a few friends, a book is read to us; after the meal we listen to a comedy or a lyre player"; and JoHNSON 2012: 58-61 for a full list of relevant passages. See also Seneca, Letters, 64, 2 for another example of reading at dinner in a Roman context, from a few decades before. 
700c. But his main treatment of communal reading, in 7, 8, is largely negative. [43] It is dedicated to debating the habit which is now widespread in Rome of having Plato's dialogues read out by slaves. An anonymous sophist speaks in favour of the practice as an alternative to other kinds of sympotic entertainment. One of the other guests, Philip, gives a horrified reply: "Spare us sir, and put an end to your abuse! For we were the first to be disgusted in Rome when this practice was introduced, and the first to attack those who think it right to make Plato an amusement over wine and to listen to the dialogues of Plato while drinking, with their desserts and their perfume" (7, 8,711 ). He then passes the conversation over to Diogenianus, who talks about what kinds of literature are suitable. Tragedy is not right for a dinner party, nor is Aristophanes, but Menander is perfectly suited, he suggests, partly because of the blend of serious and playful, which he suggests is ideal for the symposium. And then finally Plutarch speaks himself: "the only thing we must look out for is when our fellow guests are capable of entertaining each other with philosophical talk discourse, not to introduce from outside something that will be not entertainment, but rather a hindrance to entertainment" $(7,8$, 713d) - in other words something which will interrupt the pleasures of philosophical talk. The contribution of Diogenianus makes it clear that at least some of Plutarch's fellow-guests would be happy with the kinds of convivial reading we see in Pliny (who mentions comedy specifically in his depiction of Spurinna), but the undertone of negativity is hard to miss. Plutarch worries about these practices and debates them by the juxtaposition of a range of different viewpoints, whereas Pliny welcomes them without any expression of doubt. And it is hard not to see Plutarch's closing final emphasis on the importance of active involvement in philosophical conversation - a theme he returns to over and over again in the work - as the dominant message here.

In summary: I have argued here that Plutarch and Pliny have a great deal in common, not only in their friends, like Sosius Senecio, but also, more importantly, in their ambition to create vivid images of literary community, which can accommodate both Greeks and Romans, and in the miscellanistic character of their collections, which articulates the richness and varieties of the communities they present to us. It is not impossible that they knew of each other's work, but whether or not that is the case it seems clear that these two texts are similar responses to a shared set of challenges and opportunities. At the same time there are also crucial differences. In particular, they make very different choices - partly but not exclusively determined by the differences between Roman and Greek elite culture - about how their imagined communities relate to books and to the practices of reading and writing.

\section{AULUS GELLIUS}

This difference between oral and written community is even more evident when we turn to the Attic Nights of Aulus Gellius, which dates from the third quarter of the second century. It might seem odd at first sight to include it in a piece on Plutarch and Pliny, who were writing two generations before, but my argument here is that it represents a continuation and adaptation of the models of community forged by those earlier authors, and a sign of their continuing importance. [44] That is apparent for the Sympotic Questions in particular. Plutarch's text is one of Gellius' most important models, but for some reason that influence has only rarely been discussed except in passing. [45] The Attic Nights is like Plutarch's work a collection of miniature dialogues (although it also includes non-dialogue material, as we shall see below). There is no obvious model for that format in earlier Latin literature. Both texts offer us idealized images of intellectual community; both of them offer us examples of good and bad intellectual practices to imitate or avoid. Moreover the Sympotic Questions is cited by Gellius several times. [46] It is no accident that the name Plutarchus is the first word of the Attic Nights after the preface $(1,1,1)$.

And yet, like Pliny's Letters, the Attic Nights also diverges from Plutarch's approach in very striking
[43] Cf. Sympotic Questions, 1, 4, 621c for disapproval of symposiarchs reading their own compositions in symposia.

[44] For Gellius' engagement with Pliny, see JoHNSON 2012: 106, who suggests that he alludes to Pliny's Letters, 1, 15 in 19, 7.

[45] However, see BEALL 2004: 208-210 for one exception, stressing the importance of sympotic philosophy in the Socratic tradition as a model for Gellius, and Plutarch in particular; also along similar lines KEULEN 2004: 225226; HOLFORD-STREVENS 2003: 283-285; and for more detailed discussion, see HOWLEY 2018: 19-65.

[46] See Attic Nights, 3, 6, 1; 4, 11, 13; 17, 11, 6; perhaps also 3, 5, 1 and 17, 8; Holford-StReVENS 2003: 283284; BeAll 1999: 57-59, esp. n. 17. 


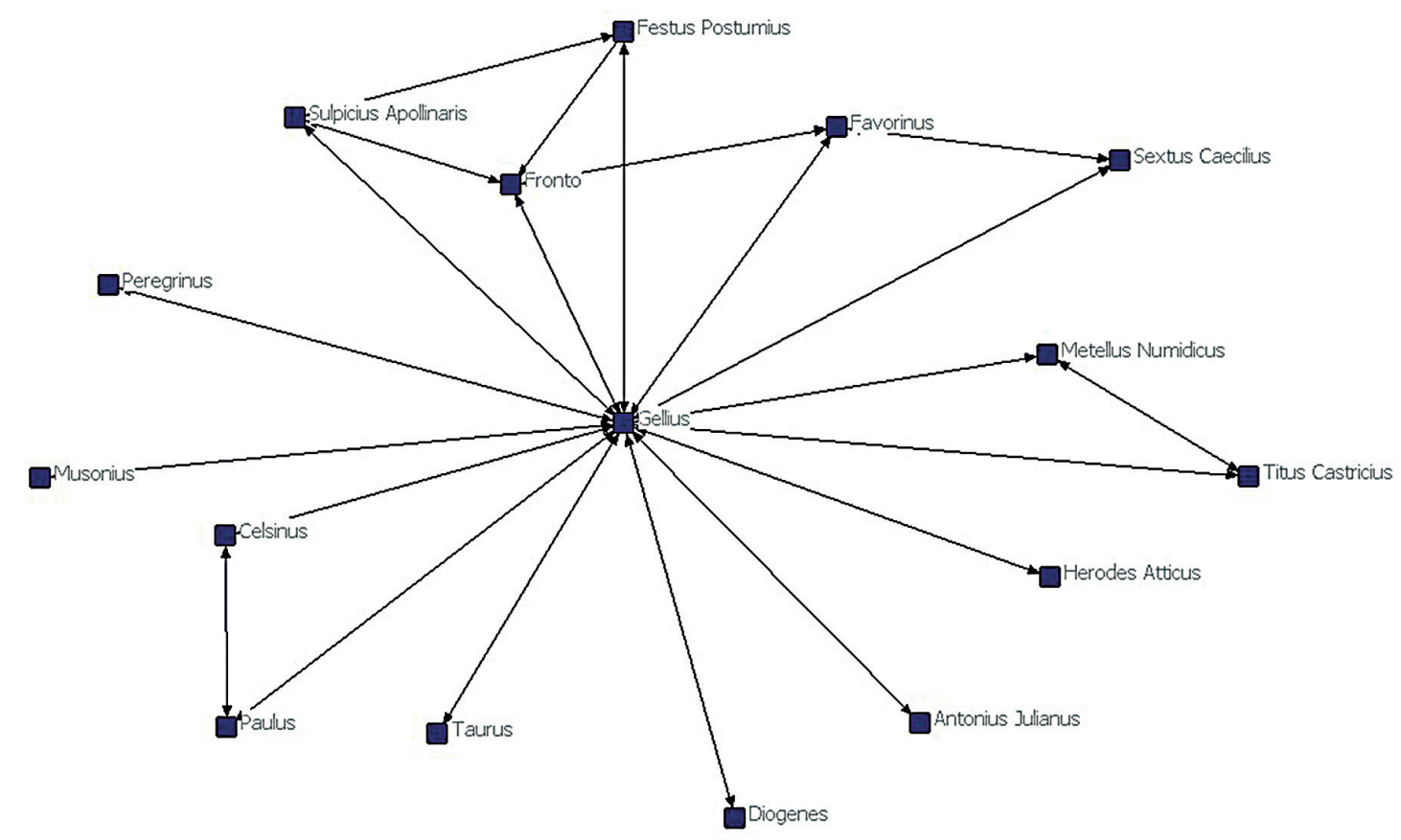

Figure 2 : Social network diagram for Aulus Gellius' Attic Nights:

lines indicate connections between individuals present at the same conversation.

ways. The most obvious difference is the pointedly Roman quality of the work. The Attic Nights shows a close knowledge of Greek literature, and makes regular reference to Plutarch and many other Greek writers, but the bulk of the work is about Latin literature and especially the Latin language. The procedures Plutarch develops in Greek are conspicuously Latinised. The Attic Nights also has a very different imaginative geography from the Quaestiones convivales. The vast majority of the chapters are set in Rome, with others in Athens, and very few anywhere else. It doesn't have anything like Plutarch's Panhellenic vision of a few key locations - Athens, Delphi, Chaironeia - set against a vast variety of other occasional settings. What we find in Gellius, by contrast, is a much a much less extensive geography, although it is not for that reason any less complicated: Gellius is interested in showing us a wide range of venues within the city of Rome itself. [47]

The intellectual community Gellius envisages is also much less tightly knit. Gellius' text includes almost exactly the same number of social encounters or conversations as Plutarch's: there are roughly 60 occasions described in both. [48] But the shape of Gellius' network graph is almost entirely different (fig. 2). There are very few connections between his characters. The vast majority of these chapters have just one named speaker in addition to Gellius. Any other interlocutors are almost always anonymous. [49] The named speakers are nearly always renowned intellectual figures, speaking authoritatively. Plutarch's community in the Sympotic Questions is didactic, with a high value attached to teacher-pupil relations, as we have seen, but the difference there is that young men are welcomed into conversation and expected to play an equal role in conversation, in line with the traditions of equality in the Greek symposium. What Gellius shows, by contrast, us is a much more unequal model of teacher-pupil relationships, in line with Roman patronage culture, and a much less interconnected model of intellectual community. [50]
[47] However, see also JoHNSON 2012: 101-102 for a list of the few venues outside Rome.

[48] In Plutarch's case two or more successive chapters are often set at the same symposium, so the count of total occasions is much less than the total number of 95 chapters.

[49] See JoHnSON 2012: 102-105 for the relatively small number of named acquaintances in the work.
[50] Gellius' portrait has a great deal in common with the models of community described by WHITE 1993: 35-45 for Augustan poetic culture in Rome: the relationship between each poet and his patron is often given a lot of attention, but there tends to be very little interest in the relationship between the poets themselves, and WHITE 1993: 36 suggests that the metaphor of the literary "circle" is inappropriate in this case. 
Closely connected with that hierarchical model of intellectual authority and community is Gellius' fascination with writing and reading. [51] Over and over again we see the Roman intellectuals of the Attic Nights discussing a problem that they have come across in a book, or consulting books as a starting-point for discussion or to solve a dispute. Sometimes that kind of communal book reading happens over dinner. As in Pliny, there are many scenes of books being read out at dinner parties. [52] 3,19 is a good example:

At the dinners of the philosopher Favorinus, after the guests had taken their places and the serving of the viands began, a slave commonly stood by his table and began to read something, either from Grecian literature or from our own. For example, one day when I was present the reading was from the treatise of the learned Gavius Bassus On the Origin of Verbs and Substantives... $(3,19,1-2)$

In Plutarch's case a quotation of that type would be from memory; it would also usually be followed by a series of attempts to explain, from different guests. But here Gellius records just a single intervention from the host Favorinus, who launches an attack on Gavius Bassus' reasoning in the quoted passage. In some other cases the use of books is even more bluntly connected with the assertion of authority. Attic Nights, 1, 2 is a case in point. It describes a scene in Herodes Atticus' villa in Athens, where Herodes silences a young and arrogant Stoic philosopher who has been pontificating over dinner:

And he gave an order for them to bring the first volume of the Discourses of Epictetus, arranged by Arrian, in which that venerable old man with just criticism rebukes young men who though calling themselves Stoics show signs neither of virtue nor honest industry, but instead babble of trivial problems... $(1,2,6)$

[51] See KEULEN 2012 (with good summary p. 313-321), on the way in which Gellius asserts his own authority through accounts of his reading, and conversely undermines the authority of recognised intellectual experts.

[52] See Johnson 2012: 127-129, listing 2, 22; 9, 9; 19,7 as well as 1,2 and 3,19.

[53] Cf. Gellius, 5, 21 for another good example; and see JoHNSON 2012: 134 for the general point: "The net result is a work suffused with claims to special access: to archives, to rare books, to famous teachers, to reports of famous teachers in the recent past...The obsessive bookishness and narrow focus on certain teachers is itself part of the claim to
In Plutarch's sympotic community speculative contributions have a high value; once again that is a manifestation of Greek sympotic traditions of equality. Here, by contrast, quotation silences dissent. [53]

Finally it is important to stress that a very large number of the chapters in Gellius' work are accounts of his own reading, focused on things he has come across in reading, and on the way in which he has puzzled over them and pursued them by looking at other books. [54] There is nothing else quite like that in earlier classical literature. One of the most distinctive features of Gellius' representation of intellectual community, in other words, is the way in which communal encounters are always to be supplemented by moments of solitude. In Gellius the assertion of intellectual authority and the experience of communing with the authors of the past are removed from the sphere of social encounter and memory and are focused instead on his own solitary experience of physical books. The performance of intellectual identity is cut loose to some extent from the experience of social interaction. In that sense Gellius is even more radical than Pliny in the degree to which he supplements a Plutarchan image of social, conversational exchange with a more book-focused model of community. [55] Aulus Gellius is thus very close to Plutarch in some respects. He clearly admired the Sympotic Questions. Not only does he refer to that earlier text explicitly; he also uses it as one of his key models - perhaps the single most important model - for his collection of vignettes of Roman intellectual life. It is also clear, however, that he distinguishes himself from Plutarch. Most strikingly, and even more so than Pliny, his obsession with books as physical objects, and his obsession with reading and writing, leads him to create an image of intellectual life and intellectual community which is in some respects completely alien to what we find in the Sympotic Questions, where learned practice is heavily dependent on consultation of written sources, even in communal and sympotic contexts, and where the special status..." I have argued in KöNIG 2012: 201-228 that the suspicion of free debate in Macrobius' Saturnalia, which dates from the early fifth century and imitates Plutarch's Sympotic Questions closely, is typical of a late antique anxiety about challenges to intellectual authority, very much in contrast with what we find in Plutarch's Sympotic Questions; it is important to stress, however, that some of that preference for single authorities is present already in Gellius, whose work Macrobius refers to repeatedly.

[54] On this phenomenon, see esp. Howley 2018: 66-111.

[55] See JoHnSON 2012: 108 on that and other differences between Gellius and Pliny. 
image of the individual encountering the great works of the past in his study or in libraries or in bookshops counts for at least as much as the traditionally Greek, Socratic model of improvisational debate.

Whether Plutarch is reacting against the book culture of late first-century Rome in reasserting that very traditional, oral model of intellectual interaction is very hard to know, although he certainly spent time in Rome, and he must have been familiar with the literary practices that Pliny describes so vividly in his letters: we have seen one example in his criticism of the fashion for reading aloud at dinner parties in Rome. Nor is it clear that Pliny has any awareness of Plutarch's work, let alone that we should view his idealized portrait of recitation culture and the constant exchange of draft compositions between his friends and acquaintances as a reaction against Greek styles of interaction - although he does show some interest in the differences between Roman and Greek modes of elite practice, for example in his description of Euphrates discussed above. It is tempting to go further, and to see the relationship between the two texts as an example of a new culture of literary interaction, of mutual imitation and dialogue between contemporary authors - certainly there are reasons to think that this was a particularly important phenomenon with the Latin literary culture of these decades. But with Pliny and Plutarch the most we can say for sure is that they are constructing closely parallel but in some respects very different solutions to the same basic challenge of bringing to life in all their richness and variety the elite communities in which they lived. Each of these texts individually, in other words, is a manifestation of that phenomenon of a new interest in literary interactivity and community; whether we can say the same for the relationship between them is less certain.

Gellius' relationship with Plutarch, by contrast, is much clearer. Plutarch is one of the most important models of all for his project in the Attic Nights: one might almost say that the great driving force for his text is the desire to construct a version of the Sympotic Questions for Romans and for Rome. But in doing that, of course, Gellius creates something very different. His narrating voice, for all its attachment to the past and the writings of the past, feels in some ways very modern. It stands in contrast with Plutarch's evocation of an elite culture founded on very old models of conversation and community (private reading is implied by Plutarch, of course, but it is rarely if ever described). Gellius includes those things, to be sure, but he also supplements them by describing over and over again his own experiences of reading. In that he is anticipated in part by Pliny [56] and some other earlier Latin writers, who are similarly interested in the motif of reading and studying at night. [57] But Gellius treats that motif with an unprecedented degree of detail; he also innovates by integrating it into a work concerned with the representation of scholarly community. In doing so he draws attention, in a much more extensive fashion than any of his predecessors, to the way in which the performance of literary community in the present is always underpinned by a process of solitary interaction with the writings of the past. [58] For Gellius, that kind of solitary interaction between reader and book matters at least as much as the kinds of social and conversational interaction that occupy almost the whole of the canvas in Plutarch's Sympotic Questions and in the broader Socratic tradition from which that work arises.

[56] For the importance of Pliny's Letters in the history of ancient representations of solitude, see WEBB 2007: 7-8.

[57] See KER 2004 and JoHnSON 2012: 114-117.

[58] For reflections on the relative infrequency of portrayals of solitude in ancient biographical and autobiographical writing, see KöNIG 2019.

\section{BIBLIOGRAPHY}

Balland, André, 2010, Essai sur la société des épigrammes de Martial, Pessac.

BEALL, Stephen M., 1999, «Aulus Gellius 17.8: composition and the gentleman scholar », Classical Philology 94, p. 55-64. BeALL, Stephen M., 2002, « Ciceronian correspondences: making a book out of letters », in T. P. Wiseman (ed.) Classics in Progress, London, p. 103-144.

BEALL, Stephen M., 2004, « Gellian humanism revisited », in Leofranc Holford-Strevens \& Amiel Vardi (ed.), The Worlds of Aulus Gellius, Oxford, p. 206-222.

BodEL, John, 2015, « The publication of Pliny's Letters », in Ilaria Marchesi (ed.), Pliny the Book-maker: Betting on Posterity in the Epistles, Oxford, p. 13-108. 
BRÉCHET, Christophe, 2007, «Vers une philosophie de la citation poétique : écrit, oral et mémoire chez Plutarque », Hermathena 182, p. 101-134.

EshlemAN, Kendra, 2012, The Social World of Intellectuals in the Roman Empire: Sophists, Philosophers, and Christians, Cambridge.

Frazier, Françoise \& Sirinelli, Jean (ed.), 1996, Plutarque - Fuvres Morales, vol. IX, 3, Paris (Collection des universités de France, série grecque 372).

FunRmANN, François (ed.), 1972, Plutarque - Euvres Morales, vol. IX, 1, Paris (Collection des universités de France, série grecque).

Gibson, Roy K. \& Morello, Ruth, 2012, Reading the Letters of Pliny the Younger: An Introduction, Cambridge.

GURD, Sean A., 2012, Work in Progress: Literary Revision as Social Performance in Ancient Rome, Oxford.

HARDIE, Philip R., 1992, «Plutarch and the Interpretation of Myth », in Aufstieg und Niedergang der römischen Welt II, 33.6, Berlin - New York, p. 4743-4787.

Hoffer, Stanley E., 1999, The Anxieties of Pliny the Younger, Atlanta.

Holford-StrevenS, Leofranc, 2003, Aulus Gellius: An Antonine Scholar and his Achievement, $2^{\text {nd }}$ ed. (1 ${ }^{\text {st }}$ ed. 1988), Oxford. Holford-Strevens, Leofranc \& VARdi, Amiel (ed.), 2004, The Worlds of Aulus Gellius, Oxford.

Howley, Joseph A., 2018, Aulus Gellius and Roman Reading Culture, Cambridge.

Johnson, William, 2012, Readers and Reading Culture in the High Roman Empire, New York.

Jones, Christopher P., 1965, « Towards a chronology of Plutarch's work », Journal of Roman Studies 56, p. 61-74.

JONES, Christopher P., 1971, Plutarch and Rome, Oxford.

KER, James, 2004, « Nocturnal writers in imperial Rome: the culture of lucubratio », Classical Philology 99, p. $209-242$. KeULen, Wytse, 2004, «Gellius, Apuleius, and satire on the intellectual », in Leofranc Holford-Strevens \& Amiel Vardi (ed.), The Worlds of Aulus Gellius, Oxford, p. 223-245.

KLotz, Frieda, 2007, «Portraits of the philosopher: Plutarch's self-presentation in the Quaestiones Convivales », Classical Quarterly 57, p. 650-667.

KLotz, Frieda, 2011, « Plutarch's peculiar presentation », in Frieda Klotz \& Katerina Oikonomopoulou (ed.), The Philosopher's Banquet: Plutarch's Table Talk in the Intellectual Culture of the Roman Empire, Oxford, p. 161-178.

KLotz, Frieda \& Orkonomopoulou, Katerina (ed.), 2011, The Philosopher's Banquet: Plutarch's Table Talk in the Intellectual Culture of the Roman Empire, Oxford.

König, Alice \& Whitton, Christopher (ed.), 2018, Roman Literature under Nerva, Trajan and Hadrian. Literary Interactions, $A D$ 96-138, Cambridge.

KöNIG, Jason, 2009, «Conventions of prefatory self-presentation in Galen's On the Order of my Own Books », in Christopher Gill, Tim Whitmarsh \& John Wilkins (ed.), Galen and the World of Knowledge, Cambridge, p. 35-58.

KöNIG, Jason, 2012, Saints and Symposiasts: The Literature of Food and the Symposium in Greco-Roman and Early Christian Culture, Cambridge.

KöNIG, Jason, 2014, «Images of elite community in Philostratus: re-reading the preface to the Lives of the Sophists », in Jesper Madsen \& Roger Rees (ed.), Roman Rule in Greek and Latin Writing: Double Vision, Leiden, p. 246-270.

KöNIG, Jason, 2016, «Re-reading Pollux: encyclopaedic structure and athletic culture in Onomasticon Book 3 », Classical Quarterly 66, p. 298-315.

KöNIG, Jason, 2019, « Solitude and biography in Jerome's Life of Hilarion », in Koen De Temmerman (ed.), Oxford Handbook of Ancient Biography, Oxford (forthcoming).

KöNIG, Jason \& WhITMARsh, Tim (ed.), 2007, Ordering Knowledge in the Roman Empire, Cambridge.

KönIG, Jason \& Woolf, Greg (ed.), 2013, Encyclopaedism from Antiquity to the Renaissance, Cambridge.

MARCHESI, Ilaria, 2008, The Art of Pliny's Letters: A Poetics of Allusion in the Private Correspondence, Cambridge.

MARCHESI, Ilaria (ed.), 2015, Pliny the Book-Maker: Betting on Posterity in the Epistles, Oxford.

MoRgAN, Teresa, 2011, «The miscellany and Plutarch», in Frieda Klotz \& Katerina Oikonomopoulou (ed.), The Philosopher's Banquet: Plutarch's Table Talk in the Intellectual Culture of the Roman Empire, Oxford, p. 49-73.

RusselL, Donald A., 1973, Plutarch, London.

SherWin-White, Adrian N., 1966, The Letters of Pliny: A Historical and Social Commentary, Oxford.

StAdTer, Philip A., 2002, «Introduction: setting Plutarch in his context », in Philip A. Stadter \& Luc Van der Stockt (ed.), Sage and Emperor: Plutarch, Greek Intellectuals, and Roman Power in the Time of Trajan, 98-117 AD, Leuven, p. 1-26. SwAIN, Simon, 1990, « Hellenic culture and the Roman heroes of Plutarch », Journal of Hellenic Studies 110, p. 126-145. SYME, Ronald, 1985, « The dating of Pliny's latest letters », Classical Quarterly 35, p. 176-185.

TEODORSSON, Sven-Tage, 2009, « The place of Plutarch in the literary genre of symposium », in José Ribeiro Ferreira, Delfim Leão, Manuel Tröster \& Paula Barata Dias (ed.), Symposion and Philanthropia in Plutarch, Coimbra, p. 3-16.

UDEN, James, 2015, The Invisible Satirist: Juvenal and Second-Century Rome, Oxford.

VAN HoOf, Lieve, 2010, Plutarch's Practical Ethics: The Social Dynamics of Philosophy, Oxford.

VARDI, Amiel, 2004, «Gellius' Noctes Atticae: genre, conventions, and cultural programme », in Leofranc HolfordStrevens \& Amiel Vardi (ed.), The Worlds of Aulus Gellius, Oxford, p. 159-187.

WebB, Diana, 2007, Privacy and Solitude in the Middle Ages, London.

WhIтE, Peter, 1993, Promised Verse: Poets in the Society of Augustan Rome, Cambridge.

Whitton, Christopher, 2013, Pliny the Younger, Epistles Book II, Cambridge.

Woolf, Greg, 2003, «The city of letters », in Catharine Edwards \& Greg Woolf (ed.), Rome the Cosmopolis, Cambridge, p. 203-221.

ZADOROJNYI, Alexei, 2013, «Libraries and paideia in the Second Sophistic », in Jason König, Katerina Oikonomopoulou \& Greg Woolf (ed.), Ancient Libraries, Cambridge, p. 377-400. 